\title{
AEROPHYTIC CYANOBACTERIA AS A FACTOR IN THE BIODEGRADATION OF TECHNICAL MATERIALS ON EXTERNAL BUILDING WALLS
}

\author{
Marlena PIONTEK ${ }^{1}$, Hanna LECHÓW \\ University of Zielona Gora, Institute of Environmental Engineering, Poland
}

\begin{abstract}
A study conducted at the Institute of Environmental Engineering, University of Zielona Gorra showed the presence of 4 species of aerophytic cyanobacteria in the biological material sampled from the external building wall with visible biocorrosion: Gloeocapsa montana Kützing, Phormidium calcareum Kützing, Aphanothece saxicola Nägeli, Gloeothece caldariorum (P.Richter) Hollerbach. High levels of moisture were detected in the places of biofilm occurrence.

Keywords: aerophytic cyanobacteria, biocorrosion, biofilm, external building wall

\section{INTRODUCTION}

Cyanobacteria are photoautotrophs, phylogenetically situated between heterotrophic bacteria and autotrophic algae. For growth, they require light, water, inorganic carbon compounds and minerals. Although they are mainly associated with water and especially with the colourful blooms, they also occur in large numbers on land $[1,18]$. They belong to Gram-negative prokaryotes. In most cyanobacteria species photosynthesis processes lead to oxygen release and species living in the anaerobic conditions make use of sulphur compounds as a source of electrons in the light stage of photosynthesis [12].
\end{abstract}

\footnotetext{
${ }^{1}$ Corresponding author: University of Zielona Gora, Institute of Environmental Engineering, Szafrana st 15, 65-516 Zielona Gora, Poland, e-mail: m.piontek@iis.uz.zgora.pl, tel.+48683282679
} 
In terms of evolution, the age of cyanobacteria is estimated at 3.5 billion years. They belong to pioneer organisms, one of the first to inhabit the surfaces of materials. Their widespread geographic distribution results from species diversity and specific metabolic strategies, which allowed them to survive under difficult stress conditions $[1,7,12,13,14,18]$. One of these methods is the excretion and external accumulation of polymer slime, mainly polysaccharides, which form a layer on the cell surface with a dual purpose: protective and facilitating interaction with the external environment [7]. Cyanobacteria are poikilohydric organisms, capable of inducing and reducing their metabolism depending on the water content. This characteristic is the reason why their growth is not limited by unfavourable periods of drought [13]. Extracellular polysaccharides of cyanobacteria have the ability to bind and retain water, which is of utmost importance in the protection against dehydration. The composition of polysaccharides depends on the species and even on the strain of cyanobacteria, yet in a majority of polysaccharides glucose it is a quantitatively dominant monosaccharide [12].

Cyanobacteria can exist in extremely difficult conditions. Their unusual resistance to water deficit and high levels of UV radiation give them advantage over many others organisms in open areas [1]. Resistance to UV radiation is connected with the synthesis of protective pigments that cause colourful blooms on e.g. building surfaces, which lowers the aesthetic value of the technical material $[5,8,15]$. In addition, cyanobacteria have great tolerance to high concentrations of salts (chlorides and sulphates) and make use of light energy beyond the range of photosynthetically active radiation (PAR) [12]. Depending on the degree of humidity and the $\mathrm{pH}$ of the surface, the thickness and colour of the coatings and the cells make it difficult to determine the species correctly [5]. For instance the pigment Gloeocapsa becomes red at $\mathrm{pH} \leq 6.5$ and above this value it changes its colour to violet and then blue [17]. Cyanobacteria affect thermal adsorptive properties of the inhabited area and as a result change the original mechanical properties of the material, contributing to its scaling and crumbling. Most importantly, however, the role of cyanobacteria in biodeterioration consists in supporting the growth of heterotrophic organisms, which have a considerable degradation potential. By transforming inorganic compounds into organic compounds in metabolic processes, cyanobacteria constitute a source of nutrients for heterotrophs with which they form biofilms $[3,4,6,7,10,15,19]$.

The microbiota on building walls represents a complex ecosystem which develops in various ways, depending on environmental conditions and the physicochemical properties of the material in question [4]. Most of the scientific to biological corrosion tests are involved in the process of bacteria and fungi, 
but growing concern for the preservation of good quality technical materials on external walls of buildings has led to increased interest in the participation of cyanobacteria in biodeterioration on external building walls. The damaging effects of cyanobacteria are generally associated with the production of protective pigments, and these cause aesthetic deterioration of the surface of buildings, as well as altering their thermal absorption characteristics [5].

The study conducted at the Institute of Environmental Engineering, UZ was aimed at demonstrating which species of aerophytic cyanobacteria in the biofilm caused the biodegradation of the external building wall.

\section{METHODS AND MATERIALS}

\subsection{Place of sampling}

The external wall of the former UZ canteen was selected for research due to its perceptible biodegradation. On the wall there was visible discolouration and signs of structure degradation: cracking, scaling and crumbling of the technical material (Photo 1.). At present, the building is not used and it is ready for renovation. The wall selected for the study is located in a shaded canteen hall, exposed to moisture due to the leaking roof. The partition selected for research is built from solid bricks and covered with lime-cement plaster.

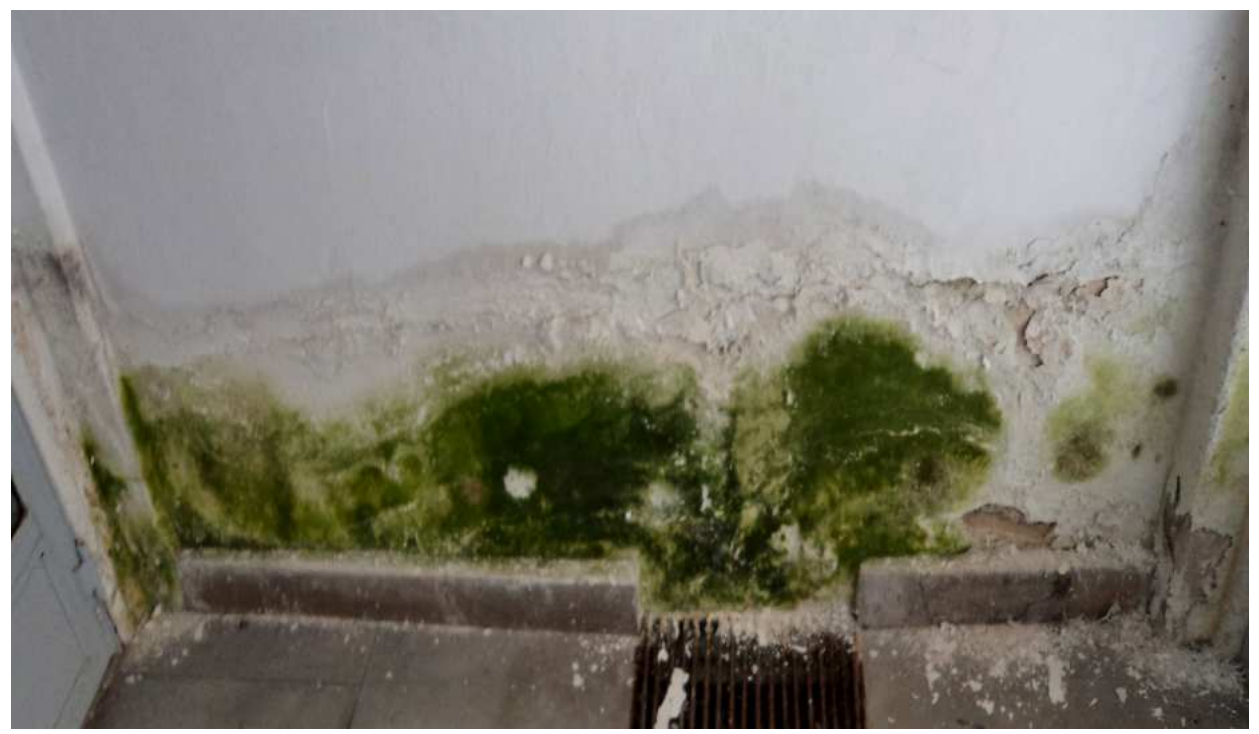

Photo 1 . The external building wall with visible biocorrosion on the building of the former UZ canteen 


\subsection{Sampling}

The material from the wall was sampled in April 2013. A fragment of biological material intended for laboratory growth and microscopic observations was taken off the wall with a sterilized scalpel. The samples were taken at three places of the bloom-covered wall (Photo 2).

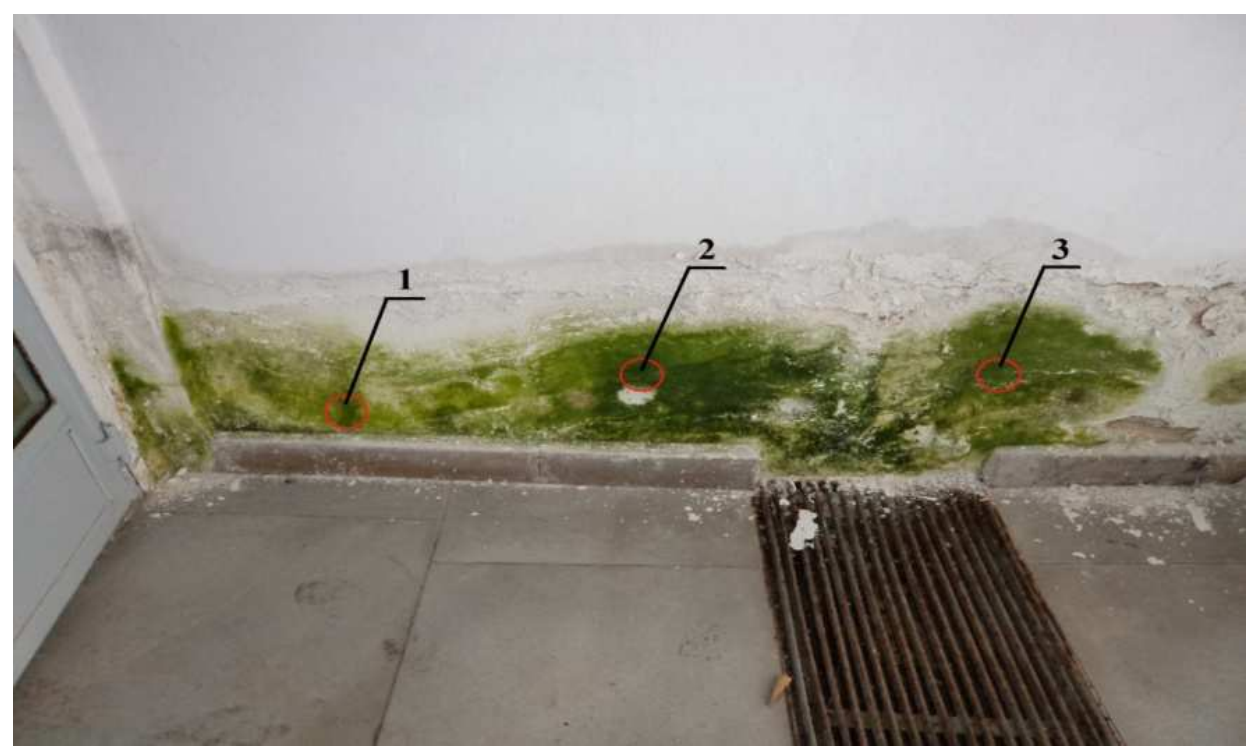

Photo 2. The three sampling points (marked 1,2,3) on the biodeteriorated external building wall

\subsection{Cultures of microorganisms for taxonomic research}

The bloom was scraped off onto a solidified Benecky substrate in sterile Petri plates. The nutrient was prepared from $30 \mathrm{~g}$ gelatin in $1000 \mathrm{ml}$ of distilled water, with the addition of $0.2 \mathrm{~g} / \mathrm{dm}^{3} \mathrm{NH}_{4} \mathrm{NO}_{3}, 0.1 / \mathrm{dm}^{3} \mathrm{CaCl}_{2}, 0.1 / \mathrm{dm}^{3} \mathrm{H}_{2} \mathrm{HPO}_{4}, 0.1$ $\mathrm{MgSO}_{4}$ and 1 drop of $1 \% \mathrm{Fe}_{2} \mathrm{Cl}_{6}$ solution. The plates were incubated in a culture room at room temperature $-18^{\circ} \mathrm{C}-22^{\circ} \mathrm{C}$ in conformity with the circadian rhythm. The cultivation time was 7 days.

\subsection{Measurement of temperature and humidity}

The measurements were taken with a Hygropen hygrometer, designed for measuring wood, building materials and air humidity as well as ambient temperature. The measurement was based on measuring electrical resistance by measuring the equilibrium moisture content in the air. There were three measurements taken at monthly intervals. 


\subsection{Identification of cyanobacteria}

After a week of cultivation the organisms were analysed using a Nikon Eclipce 200 optical microscope fitted with a digital camera as well as an identification key[17] and atlas [11]. The traditional technique of cyanobacteria identification was based mainly on observation of their morphological characteristics.

\section{RESULTS}

The results of the measurements with a Hygropen hygrometer are presented in Table 1.

Table 1.The summary of the results of the temperature and humidity measurements taken with a Hygropen hygrometer

\begin{tabular}{|c|c|c|c|c|}
\hline $\begin{array}{c}\text { Measurement } \\
\text { months }\end{array}$ & $\begin{array}{c}\text { Air } \\
\text { temperature } \\
{\left[{ }^{\circ} \mathrm{C}\right]}\end{array}$ & $\begin{array}{c}\text { Air humidity } \\
{[\%] \mathrm{RH}}\end{array}$ & $\begin{array}{c}\text { Humidity of } \\
\text { area with no } \\
\text { bloom } \\
{[\%] \mathrm{RH}}\end{array}$ & $\begin{array}{c}\text { Humidity of area } \\
\text { with biological } \\
\text { bloom } \\
{[\%] \mathrm{RH}}\end{array}$ \\
\hline February & 9 & 39 & 55.5 & $\begin{array}{c}\mathrm{HI}-\text { exceeding } \\
\text { measuring range }\end{array}$ \\
\hline March & 12.5 & 35.5 & 57.3 & $\begin{array}{c}\mathrm{HI}-\text { exceeding } \\
\text { measuring range }\end{array}$ \\
\hline April & 18.5 & 66 & 59 & $\begin{array}{c}\mathrm{HI}-\text { exceeding } \\
\text { measuring range }\end{array}$ \\
\hline
\end{tabular}

$\mathrm{HI}>85 \% \mathrm{RH}$

RH (Relative Humidity) e.g. (1) of an air-water mixture is defined as the ratio of the partial pressure of water vapour $\left(\mathrm{H}_{2} \mathrm{O}\right)\left(\mathrm{e}_{\mathrm{w}}\right)$ in the mixture to the equilibrium vapour pressure of water $\left(\mathrm{e}_{\mathrm{w}}\right)$ at a given temperature.

$$
\phi=\frac{e_{w}}{e^{*}{ }_{w}} \times 100 \%
$$

The results in Table1. show that the humidity of areas with no bloom is similar in the three treatment months. In contrast to the areas with biological bloom humidity highly increased. Growth of microorganisms in the biofilm on the facade caused a distinct change in humidity in the area of the facade.

The following cyanobacteria species were identified:

- Gloeocapsa montana Kützing (Photo 3) frequently occurs on moss, moist rocks and walls. Spherical or slightly elliptical cells, usually enclosed in broad, colourless, delicately concentrically layered coatings [17]. 


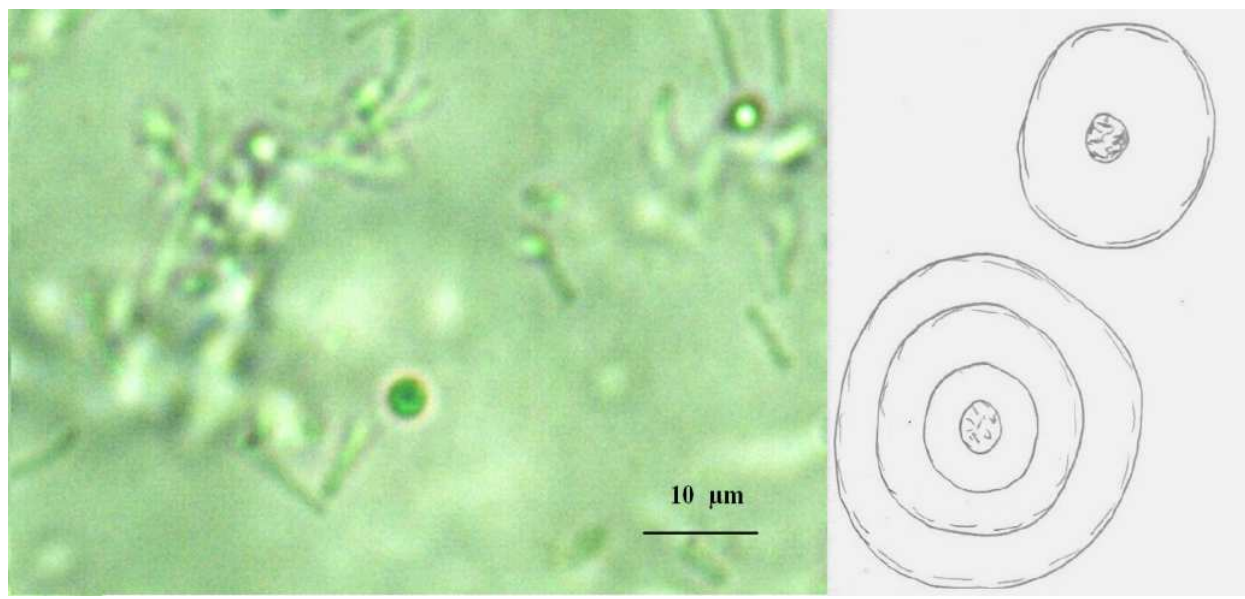

Photo 3. Gloeocapsa montana Kützing (on the left: microscopic image, on the right: sketch of view)

- Phormidium calcareum Kützing (Photo 4) occurring on damp limestone. Layered, light blue and green, leathery thalli. The cell tip sharply conical, sometimes with capitate, nearly spherical formation on top [17].

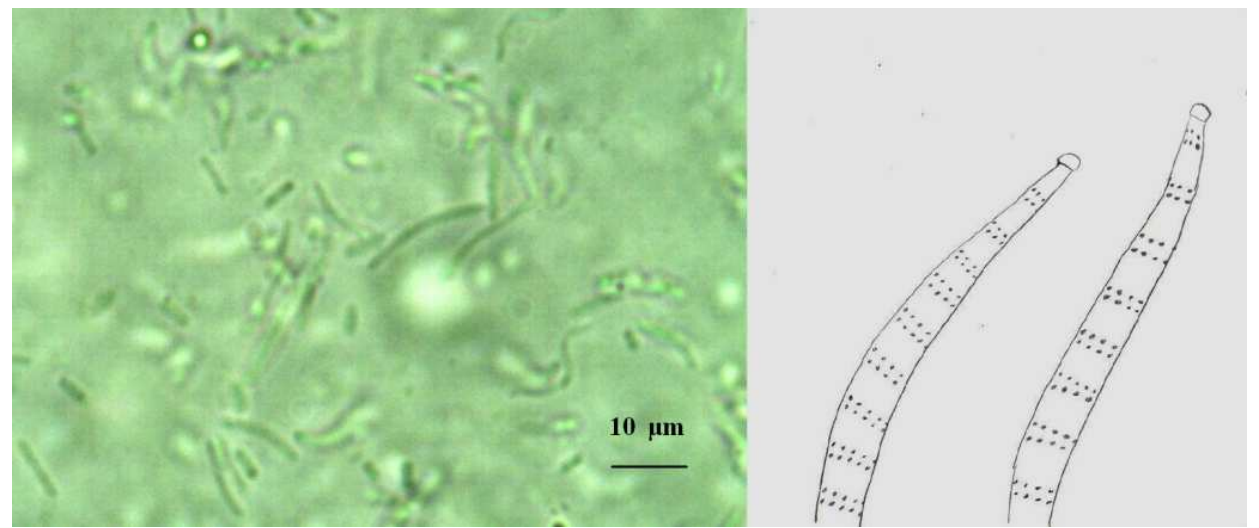

Photo 4. Phormidium calcareum Kützing (on the left: microscopic image, on the right: sketch of view)

- Aphanothece saxicola Nägeli (Photo 5) occurs on moist rocks and walls. Microscopic spherical colonies blending into shapeless gelatinous thalli, pale blue and green, occasionally yellowish or violet in colour. Long, cylindrical cells, single or in pairs. 


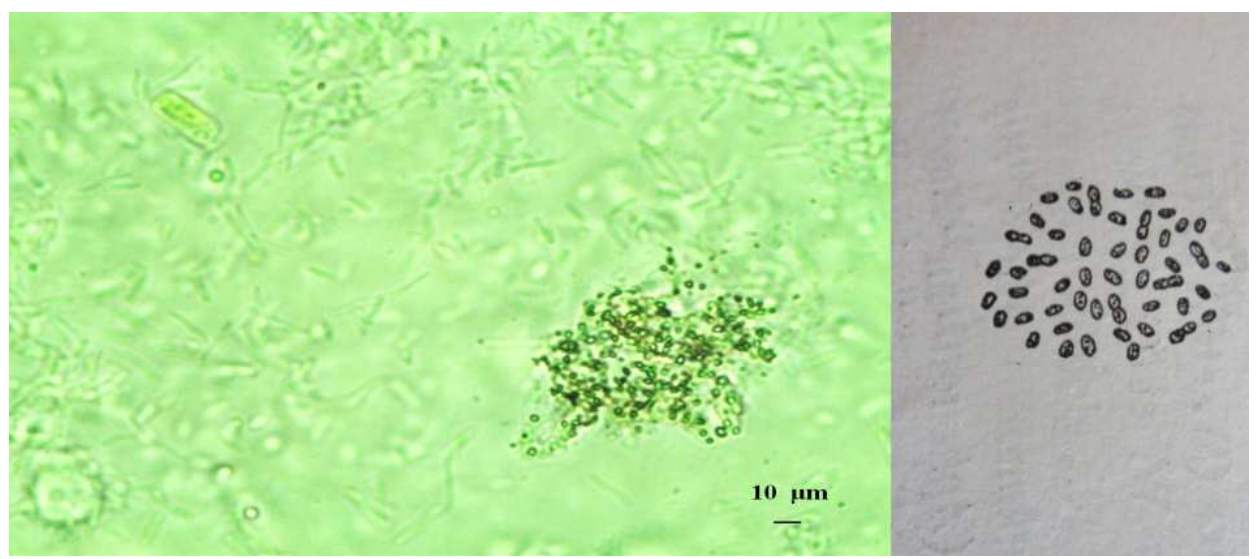

Photo 5. Aphanothece saxicola Nägeli (on the left: microscopic image, on the right: sketch of view)

- Gloeothece caldariorum (P.Richter) Hollerbach (Photo 6) also occurs on moist rocks and walls. Broadly spread gelatin coatings consisting of single or double cells with a single glossy grain at either end [17].
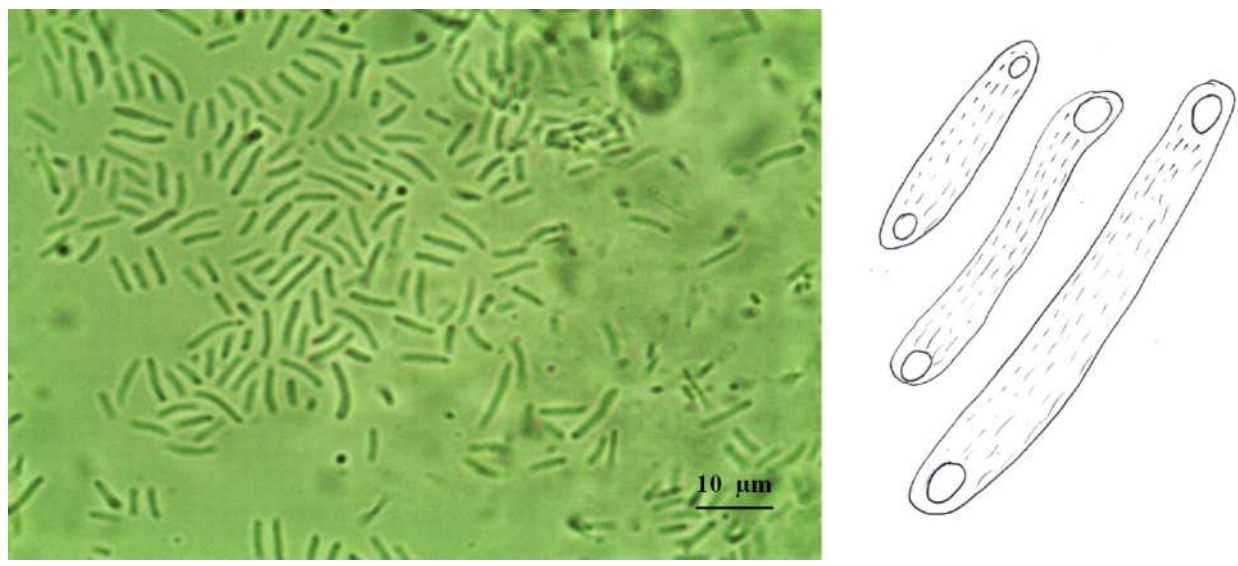

Photo 6. Gloeothece caldariorum (Richter) Hollerbach (on the left: microscopic image, on the right: sketch of view)

\section{DISCUSSION}

External building walls are exposed to biocorrosion caused by biological factors commonly occurring in the environment. Biological infections and the intensity of biodeterioration processes are strongly influenced by water availability. This is determined by both, material-specific parameters, like porosity and 
permeability, as well as the environmental conditions of the site and exposure of the object [19]. Microorganisms colonizing the elevation surfaces initially do not cause any noticeable change, but with time they may cause visual changes and physicochemical damage to the technical material. The most frequently occurring organisms on building surfaces are: bacteria, cyanobacteria, actinobacteria, algae, fungi and protozoa. Because of their resistance to water deficit and the adverse UV radiation, cyanobacteria, fungi and algae constitute most of the biomass in blooms on external building walls more frequently than other organisms [9]. Aerophytic cyanobacteria form symbiotic environments with heterotrophic organisms (bacteria, moulds). In metabolic processes they produce alkaline substances or aggressive acids (sulphuric acid, nitric acid and others) as well as surfactants [6], which by reacting with the substrate cause irreversible changes to the wall structure, enabling microorganisms to permeate the technical material. The cyanobacteria species occurring on the plaster of residential buildings, similarly to litophytes, acquire nutrients from the atmosphere, precipitation, as well as dust and dirt. The processes of biodeterioration in which cyanobacteria take part are partly due to the excretion of corrosive acids, the accumulation of sulphur and calcium in the cells, or due to their permeation of the technical material, which leads to changes in stress levels and its degradation [6]. Cyanobacteria also create biofilms which are a mixture of adsorbed inorganic compounds which come from the colonized area and the air, dead cells, the by-products of metabolism and a layer of polysaccharides. Biological films form corrosive microenvironments in which acids are produced as by-products of the processes of respiration and photosynthesis [19].

Cyanobacteria also contribute to the unaesthetic discolouration of the surface $[1,2,3,4,5,11,16,19]$. This is due to the fact that on the outer surfaces of their cells, in the chromatoplasm, there are protective pigment complexes which contain chlorophyll a, b-carotene, c-phycocyanin and phycobiliproteins, including phycoerythrin - the red pigment as well as phycocyanin - the blue pigment, and others. Cyanobacteria are capable of controlling particular pigment proteins on the level of transcription of protein-coding genes, regulating them depending on the type of radiation [7]. The number of pigments is changing and the cells assume various colours: blue and green, olive green, yellow and green, pink, brown, black and others [12,17].

The intensity of deterioration caused by microorganisms, including cyanobacteria depends on a number of factors such as: the temperature, air humidity, the speed and direction of the wind, exposure to sunlight and the vicinity of green areas. All these factors increase the emission of biological 
pollution. The $\mathrm{pH}$ value and the physical and chemical properties are also of importance $[9,17]$.

The research into the qualitative composition of the biofilms occurring on external building walls carried out in Europe and Latin America determined that cyanobacteria were the most frequently occurring organisms in blooms on buildings in America, whereas in Europe they ranked second to algae [9]. The differences in quantitative composition result from different climatic conditions on the two continents. The authors concluded that the species composition of the studied biofilms depended on the climate and not on the composition of the substrate. Research conducted in various parts of the world shows that organisms also make use of the compounds contained in the material on which they deposit. Materials with nutritional value are especially easily degraded [16].

\section{CONCLUSIONS}

The external building wall discussed in the paper provided conditions conducive to the colonization and growth of organisms causing biocorrosion. The degradation of technical material was very clear and it was characterized by surface discolouration and the destruction of the structure by numerous cracks and layer separation. During the research high moisture was detected in the areas with biological blooms. In the biofilm on the elevation aerophytic cyanobacteria were detected. Four species of cyanobacteria were identified. They all contributed to the creation of biological bloom on the wall and the initiation of biodeterioration processes of the technical materials.

\section{REFERENCES}

1. Algae and Cyanobacteria in Extreme Environments, edited by J.Seckbach, Springer 2007.

2. Arino X., Saiz-Jimenez C.: Colonization and deterioration processes in Roman mortars by cyanobacteria, algae and lichens, Aerobiologia, 12 (1996), 9-18.

3. Barberousse H. H., Ruot B., Yéprémian C., Boulon G.: An assessment of facade coatings against colonisation by aerial algae and cyanobacteria, Building and Environment, 42 (2007), 2555-2561.

4. Crispim, C.A., Gaylarde, C.C.: Cyanobacteria and Biodeterioration of Cultural Heritage: A Review, Microbial Ecology , 49, 1 (2005),1-9.

5. Crispim,C.A., Gaylarde, P.M., Gaylarde, C.C., Neilan, B.A.: Deteriogenic cyanobacteria on historic buildings in Brazil detected by culture and 
molecular techniques, International Biodeterioration \& Biodegradation, 57 (2006), 239-243.

6. Crispim, C.A., Gaylarde, C.C., Gaylarde, P.M.: Biofilms on church walls in Porto Alegre, RS, Brazil,with special attention to cyanobacteria, International Biodeterioration \& Biodegradation, 54 (2004), 121-124.

7. Cyanobacterial Biofilms in Monuments and Cares, in: Ecology of Cyanobacteria II: Their Diversity in Space and Time, edited by B.A. Whitton, Springer 2012, 317-336.

8. Gaylarde, P.M., Gaylarde, C.C.: Algae and cyanobacteria on painted buildings in Latin America, International Biodeterioration \& Biodegradation, 46 (2000), 93-97.

9. Gaylarde, C.C., Gaylarde, P.M.: A comparative study of the major microbial biomass of biofilms on exteriors of buildings in Europe and Latin Americ, International Biodeterioration \& Biodegradation, 55 (2005), 131139.

10. Gaylarde, C.C., Morton, L.H.G., Loh, K., Shirakawa, M.A.: Biodeterioration of external architectural paint films - A review, International Biodeterioration \& Biodegradation , 3 (2011), 1189 -1198.

11. Hindak F.: Colour atlas of cyanophytes, Publishing House of the Slovak Academy of Science, Bratislava 2008.

12. Lechowski, Z., Białczyk, J.: Rola $i$ znaczenie polisacharydów sinic $w$ przyrodzie i biotechnologii, Wiadomości botaniczne, 45 (2001), 35-51.

13. Miller, A.Z., Sanmartín, P., Pereira-Pardo, L., Dionísio, A., Saiz-Jimenez, C., Macedo, M.F., Prieto, B.: Bioreceptivity of building stones: A review, Science of the Total Environment, 426 (2012), 1-12

14. Neilan, B.A., Burns, B.P., Relman, D., Lowe, D.R..: Molecular identification of cyanobacteria associated with stromatolites from distinct geographical locations, Astrobiology, 2 (2002), 271-280.

15. Ortega, J.J., Hernandez,M. M., Saiz, J.C.: Biodeterioration of building materials by Cyanobacteria and algae, International Biodeterioration \& Biodegradation, 28 (1991), 165-186.

16. Piontek, M.; Lechów, H.: Deterioracja elewacji zewnetrznych wywołana biofilmem, Zeszyty Naukowe Uniwersytetu Zielonogórskiego, 151 (2013), str.79-87.

17. Starmach K.: Cyanophyta-Sinice, Glaucophyta-Glaukofity, PWN, Warszawa 1966.

18. Subashchandrabose, S.R, Ramakrishnan, B., Megharaj, M., Venkateswarlu, K., Naidu, R.,: Mixotrophic cyanobacteria and microalgae as distinctive biological agents for organic pollutant degradation, Environment International, 51 (2013), 59-72. 
19. Warscheid, T.; Braams, J.: Biodeterioration of stone: a revie, International Biodeterioration \& Biodegradation, 46 (2000), 343-368.

\section{SINICE AEROFITYCZNE JAKO JEDEN Z CZYNNIKÓW BIODEGRADACJI MATERIAŁÓW TECHNICZNYCH NA ELEWACJACH ZEWNĘTRZNYCH}

\section{Streszczenie}

Badania przeprowadzane w Instytucie Inżynierii Środowiska UZ wykazały w materiale biologicznym, pobranym $\mathrm{z}$ elewacji $\mathrm{z}$ widoczną korozją biologiczną, obecność 4 gatunków sinic aerofitycznych: Gloeocapsa montana Kützing, Phormidium calcareum Kützing, Aphanothece saxicola Nägeli, Gloeothece caldariorum (P. Richter) Hollerbach. W miejscach występowania biofilmu, stwierdzono wysoką wilgotność.

Słowa kluczowe: $\quad$ sinice aerofityczne, biokorozja, biofilm, elewacje zewnętrzne

Editor received the manuscript: 28.08 .2014 